https://www.amerabra.org; https://fspu.uitm.edu.my/cebs; https://www.emasemasresources.com/ $5^{\text {th }}$ ABRA International Conference on Quality of Life Holiday Villa Langkawi, Langkawi Island, Malaysia, 15-16 Dec 2021

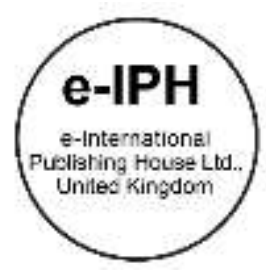

\title{
Rural Area School Teacher's Technology Adoption: Lessons learned from the COVID-19 phenomenon
}

\author{
Rusnani Mohamad Khalid ', Shaherah Abdul Malik ${ }^{2}$, Nurul Aien Abd Aziz ${ }^{2}$, \\ Mohd Hafizan Musa ${ }^{1}$, Noreen Noor Abd Aziz ${ }^{2}$
}
${ }^{1}$ Faculty of Computer and Mathematical Sciences, Universiti Teknologi MARA Cawangan Johor, Kampus Segamat, Malaysia ${ }^{2}$ Faculty of Business Management, Universiti Teknologi MARA Cawangan Johor, Kampus Segamat, Malaysia

rusna162@uitm.edu.my, shahe314@uitm.edu.my, nurul106@uitm.edu.my, mohdh233@uitm.edu.my,noree974@uitm.edu.my Tel: 017-7907274

\begin{abstract}
The occurrence of Covid-19 has caused the existing school learning system to move to online teaching and learning methods. They are carried out to safeguard the continuity of school learning sessions, attempting to avert dropouts. This paper analyzes the relationships between organizational factors, perceived usefulness, personal innovativeness, and peers with technology adoption among teachers in rural schools in Segamat District. A total of 117 teachers were involved in this study. The results showed that perceived usefulness, personal innovativeness, and peers influenced technology adoption among teachers from rural schools.
\end{abstract}

Keywords: Adoption, e-learning, technology

eISSN: 2398-4287@ 2021. The Authors. Published for AMER ABRA cE-Bs by e-International Publishing House, Ltd., UK. This is an open access article under the CC BYNCND license (http://creativecommons.org/licenses/by-nc-nd/4.0/). Peer-review under responsibility of AMER (Association of Malaysian Environment-Behaviour Researchers), ABRA (Association of Behavioural Researchers on Asians/Africans/Arabians) and cE-Bs (Centre for Environment-Behaviour Studies), Faculty of Architecture, Planning \& Surveying, Universiti Teknologi MARA, Malaysia.

DOI: https://doi.org/10.21834/ebpj.v6i18.3059

\subsection{Introduction}

The outbreak of the COVID-19 pandemic in March 2020 has changed the landscape of the educational field in the Malaysian context. According to Zhang, Wang, Yang, and Wang (2020), this pandemic has forced all countries to sequence emergency management mechanisms. The Malaysian government's movement control order that aims to curb the spread of COVID-19 has led to the implementation of home-based learning methods. Around November 2020, the Ministry of Education Malaysia introduced an initiative to implement teaching and learning methods at home, known as PDPR (Home-based teaching and learning). This situation changed the pattern of teaching and learning activities from face-to-face learning to online learning. Through this method, teachers conduct online teaching sessions and knowledge delivery. Teachers and students become more exposed to new platforms like Microsoft Teams, Google Hangouts, etc. However, the teachers face difficulties providing quality learning materials, the lack of online teaching experiences, and the inability to assess students' comprehension. The students and the parents were given clear instructions and norms to help them adjust to this novel learning channel and ensure that lessons ran successfully (Saxena, 2020).

The online learning system is defined as distance learning, online learning, and network learning (Wilson, 2001). Online learning methods help promotes interaction between teachers and students (Holley, 2002). Online learning may be accomplished in various ways, such as digital slide shows, digital graphic information, etc. The use of technology in learning sessions has raised more creative ideas for lecturers to convey knowledge. The use of technology is an excellent opportunity for schools to explore the potentials of online learning

eISSN: 2398-4287C 2021. The Authors. Published for AMER ABRA cE-Bs by e-International Publishing House, Ltd., UK. This is an open access article under the CC BYNCND license (http://creativecommons.org/licenses/by-nc-nd/4.0/). Peer-review under responsibility of AMER (Association of Malaysian Environment-Behaviour Researchers), ABRA (Association of Behavioural Researchers on Asians/Africans/Arabians) and cE-Bs (Centre for Environment-Behaviour Studies), Faculty of Architecture, Planning \& Surveying, Universiti Teknologi MARA, Malaysia.

DOI: https://doi.org/10.21834/ebpj.v6i18.3059 
methods-various platforms the teachers use in implementing teaching sessions. Although technology in teaching and learning has long been introduced yet, each time a new material or technology tool was presented in education; it became a concern and uncomfortable to some teachers (Mohamed Noh et al., 2013). However, to ensure a smooth running of online teaching sessions, there are needs to be studied regarding the factors that contribute to teachers' adoption of technology (Aziz et al., 2020). These factors must be checked because they contribute to educational leaders and policymakers who want to promote technology integration in the classroom (Sangeeta \& Tandon, 2020). In addition, there are also several challenges from the perspectives of teachers to move from offline to online mode of learning (Ferri et al., 2020). Engaging students and indulging them in teaching-learning progression is yet another stumbling block in the adoption of online teaching. Voogt and Knezek (2008) indicated that the teachers' use of technology is affected by their attitudes, competence, and access to technology. The institution's failure to recognize the underlying reasons for these issues would also disrupt the process of imparting knowledge to students by educators (Aziz et al., 2020). This research is an effort to understand the factors that encourage online teaching adoption during the COVID-19 pandemic-induced lockdown. Hence, this study investigates the relationship between organizational factors, perceived usefulness, personal innovativeness, and peers with teachers' adoption of technology. This study is also expected to strengthen further the education system using technology from the Malaysian context.

\subsection{Literature Review}

Nowadays, various new educational technologies have been adopted and integrated into the curriculum with varying degrees of success. Some people will embrace modern technology-based teaching methods, while others will reject them. However, the adoption of educational technology is very challenging, and it is not as easy as people might think. Due to this, organizations play an essential role in technology adoption. They need to provide solid technological supports and good infrastructures to avoid the barriers to technology adoption. According to Agyei and Voogt (2011) and Dinh (2009), poor infrastructure is one of the main barriers to the adoption of technology in educational settings.

Since technology is evolving so rapidly, it is impossible to compile a body of knowledge for anyone's application across time. When facing new technology, most people go through an implementation of a decision process in which they collect information, validate the technology, and then determine whether it provides a necessary change to justify the time and effort taken to incorporate it into their skills (Goktalay\& Ocak. 2006). When looking at technology adoption, Sherry and Gibson (2002) recommended that the organizational aspect be weighed. According to Kotrlik and Redmann (2009), the school environment's culture should be examined to see if it is conducive to future advancements and technology in teaching. In addition, the school's culture motivates or inhibits the teachers' willingness to use Information and Communications Technology (ICT) (Tearle, 2004).

According to Brinkerhoff (2006), institutional and administrative support, preparation and experience, attitudinal or personality, influences, and resources are all barriers that prevent teachers from maximizing technology's instructional potential. According to Andoh (2012), organizational considerations aid the improvement of the current instructor's characteristics. Technology usage in the classroom is influenced by the number of time teachers devote to teaching and the amount of technology education they receive.

Some teachers in rural areas want more access to ICT services and technical support when they run into difficulties - these are clear examples of how to integrate ICT into English teaching effectively and administrative support (Mai \& Hong, 2014). Teachers' IT expertise should be upgraded over time, according to Ya'acob et al. (2005), and instruction should be given on a continuous rather than one-time basis. Furthermore, school leaders should form industry-teacher collaborations to offer ICT training programs tailored to teachers' needs (Lau \& Sim, 2008).

Educational change begins with a teacher's thoughts and actions. Andoh (2012) claims that if teachers are given time to practice with technology, learn, communicate, and collaborate with peers, they are more likely to incorporate them into their teaching. Aside from selfstudy, teachers learn from their peers, especially the more experienced ones. They had to observe all kinds of classes during their teaching probation time. This means that teachers should continue using their peers as training sources. According to Thomas et al. (2002), teachers with technical competence should get mentor training so that they may better support their colleagues.

Good motivation may also be associated with teachers who promote and motivate their peers to use online learning. These educators will also share their experiences with colleagues who are unwilling to use technology. Mentor teachers' workloads can also be revised, according to Thomas et al. (2012), so that they can mentor more teachers without being overburdened. The interactions of peers who are doing some tasks on a specific technology affect the teaching community (Tandon \& Sangeeta, 2020).

In rural areas especially, teachers ought to be encouraged by their peers to undergo pedagogy instruction to integrate ICT in the classroom (Mai \& Hong 2014; Duyen, 2014). According to Mai and Hong (2014), the affordability and usability of ICT hardware, software, technological assistance, and motivation from coworkers and administrators are all critical factors. Most of the respondents believe that their coworkers' use of ICT motivates them to use it. This peer factor influences whether ICT inclusion is encouraged or discouraged in the classroom. The majority of teachers are hoping for more supports from their colleagues, as well as more computer pieces of training.

Perceived usefulness is the degree of a person's confidence in using a particular system to enhance their daily job performance. According to Davis et al. (1992), perceived usefulness is defined as the consumers' perceptions regarding the outcome of the experience after using a particular system. In Davis (1989), perceived ease of use is the degree to which a person believes that using a specific system would be free of physical and mental effort. This variable is taken from the original Technology Acceptance Model (TAM) model, popularly used to test information systems theory that models how users come to accept and use technology. Recently, a few studies had tested this variable specifically in the education field during the COVID-19 pandemic. Also, the results in Aziz et al. (2021), Samuel (2014), Thongmak (2017), and Thanakrit et al. (2019) showed significant results in their studies. 
Innovativeness is a procedure of introducing or applying a new idea or method in a person's routine. It may be described in various forms, such as product or process innovation, radical or incremental innovation, administrative or technological innovation, and more (Zaltman et al.,1973). The person who creates this new idea or method is called an innovator, while personal innovativeness is defined as the level of a person's willingness to try out this new idea or method (Bambang, 2019). According to Donald et al. (2019), personal innovativeness introduces a new method of information system applied across several fields, including strategic investment and organization management.

ICT incorporation into teaching and learning is highly complex, and it is easy to run into a variety of challenges, which are often referred to as "barriers" (Schoepp, 2005). Adoption, as described by Rangaswamy and Gupta (2000), is the decision that individuals make each time they consider adopting new technology. Similarly, Rogers (2003) describes adoption as an individual's decision to use new technology as the best course of action.

According to Rogers (2003), the adoption process begins with the first hearing regarding an invention and ends with the final adoption. The concept of adoption used in this research is Rogers'. Earle (2002) related ICT integration to the idea of wholeness, which occurs when all components of a system are connected to form a whole. Williams (2003) described ICT integration as using any ICT tool (the Internet, e-learning technology, CD ROMs, and so on) to aid teaching and learning. Williams' concept of ICT integration is used for this analysis.

Tandon, U. (2020) revealed that adopting online teaching is commendable during COVID-19 times, and it is also critical to establish and improve the standards of education and courses provided during the pandemic. However, from a study from Ghana, constraints imposed by an insufficient number of computers in institutions, poorly qualified educators, and the lack of internet access are the significant barriers to ICT implementation in teaching and learning (Mereku et al., 2009).

Researchers have identified several factors that influence the acceptance and incorporation of ICT in the classroom. According to Rogers (2003), five technical characteristics or qualities affect the decision to implement new technology. When it comes to ICT adoption and incorporation, Sherry and Gibson (2002) argued that technical, human, organizational, and institutional factors should all be considered. Neyland (2011) found that macro factors like institutional support and micro factors like teacher capacity influence online learning in Sydney high schools.

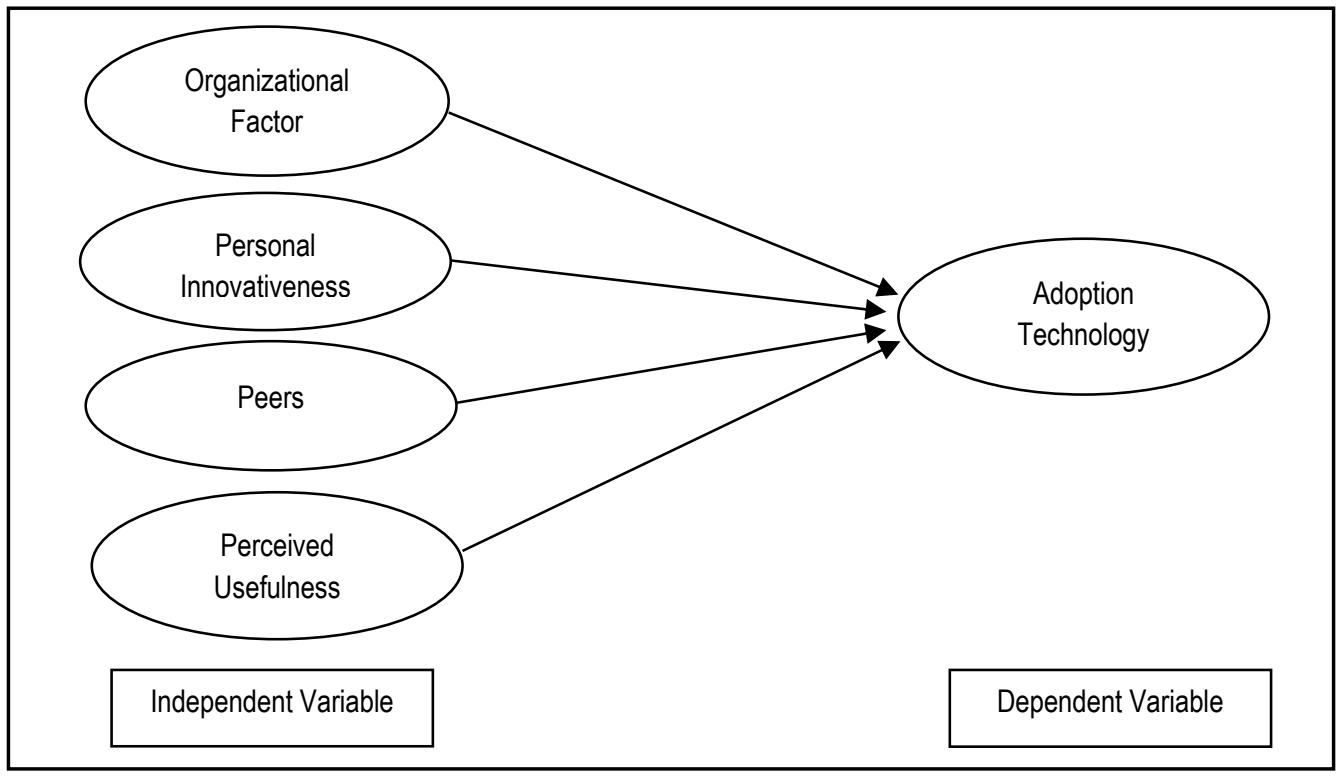

Figure1: Theoretical Framework

\subsection{Methodology}

This study employed descriptive research and used a questionnaire to gather the data. The researchers personally administrated the questionnaire. The respondents were asked to assess the factors towards technology adoption at 5-point Likert (1=strongly disagree, and $5=$ strongly agree). The questionnaire was adopted and adapted from several studies such as marketing, organizational behavior, management, and other areas of study. The survey method was used to investigate the factors that influence technology adoption among teachers in a rural area school. The questionnaire's instrument comprised demographic profiles of teachers, organizational factors, personal innovativeness, peers, perceived usefulness, and technology adoption. The questionnaire was drafted in English for easier understanding and considering that the education level of most respondents was up to tertiary's level. The researcher seeks permission and assistance from Pejabat Pendidikan Daerah Segamat to enable a smoother distribution of questionnaires. Enumerators, with the researcher's supervision, were appointed for this purpose. The main advantage of this method is the efficiency in obtaining data in terms of researchers 'time, energy, and costs. This method can also establish rapport and motivate respondents, and simultaneously, doubts can be clarified in a less expensive way when carried out with a group of respondents. A simple random sampling technique was employed in selecting the prospective respondents. Cross-sectional surveys used questionnaires to obtain the required data. A total of 117 
respondents comprising of primary and secondary rural school teachers in the Segamat district were involved in this study. The researchers monitored the distribution process of the questionnaires until they were completed to ensure a high response rate. The data gained from the survey were analyzed using Social Science Statistics Package version 25 (SPSS). Besides using descriptive statistics, this study also employed Pearson correlation to test and investigate the variables' relationships.

\subsection{Findings}

\subsection{Demographic Analysis}

\begin{tabular}{llll}
\multicolumn{5}{c}{ Table 1: Demographic Profile $(\mathrm{n}=117)$} & \\
\hline Demographic & & Frequency & Percent \\
\hline Gender & Male & 30 & 25.6 \\
\hline Age & Female & 87 & 74.4 \\
\hline & $21-29$ years old & 16 & 13.7 \\
\hline & $30-39$ years old & 27 & 23.1 \\
\hline Race & $40-49$ years old & 43 & 36.8 \\
\hline & 50 years and above & 31 & 26.5 \\
\hline & Chinese & 2 & 1.7 \\
\hline Education & Indian & 1 & 0.9 \\
\hline & Malay & 114 & 97.4 \\
\hline & Diploma & 8 & 6.8 \\
\hline & Bachelor's degree & 99 & 84.6 \\
\hline & Master & 9 & 7.7 \\
\hline
\end{tabular}

Generally, the respondents in this study were mainly females (74.4\%; 87); whilst males made up only $25.6 \%$ (30) of the sampled group. Apart from that, most of the respondents were above 50 years old $(31 ; 26.5 \%)$, and most of them were above 40 years old $(43,36.8 \%)$. The Malays made up $97.4 \%$ (114), followed by other races such as Chinese $(1.7 \%, 2)$ and Indians $(0.9 \%, 1)$. In terms of background, the majority of the teachers received bachelor's degree education $(99,84.6 \%)$.

\subsection{Reliability Analysis}

Table 2: Reliability Statistics

\begin{tabular}{|l|c|c|}
\hline Variables & Number of items & Cronbach Alpha \\
\hline Adoption of Technology & 5 & 0.905 \\
\hline Organizational Factor & 6 & 0.885 \\
\hline Perceived Usefulness & 5 & 0.906 \\
\hline Personal Innovativeness & 5 & 0.592 \\
\hline Peers & 4 & 0.874 \\
\hline
\end{tabular}

Table 2 determines the results of all the variables tested in the study. It shows a significant variation of Cronbach's Alpha values fluctuating from .592 to 0.905 . A Cronbach's alpha value must be greater than 0.70 to be an accepted value (Nunally \& Bernstein, 1994). This study shows that the values of Cronbach's alpha for organizational factors, perceived usefulness, personal innovativeness, peers, and adoption are acceptable and valid.

\subsection{Correlation Analysis}

Table 3 determines the correlations between all variables, and all the variables were positively and significantly correlated between the variables $(p<.01)$. The values indicate that all variables used in this study had a stable association with each other.

\begin{tabular}{|c|c|c|c|c|c|c|}
\hline Variables & & 1 & 2 & 3 & 4 & 5 \\
\hline 1. & Peers & - & & & & \\
\hline 2. & Organizational Factor & $0.801^{* *}$ & & & & \\
\hline 3. & Perceived Usefulness & $0.795^{\star *}$ & $0.715^{\star *}$ & & & \\
\hline 4. & Personal Innovativeness & $0.491^{* *}$ & $0.440^{* *}$ & $0.494^{* *}$ & & \\
\hline 5. & Adoption & $0.664^{* *}$ & $0.512^{\star *}$ & $0.694^{* *}$ & $0.491^{* *}$ & - \\
\hline
\end{tabular}

\subsection{Analysis of the coefficient of Determination}

Table 4: Analysis of the coefficient of Determination $\left(R^{2}\right)$

\begin{tabular}{ll}
\hline Model & 1 \\
\hline$R$ & 0.738 \\
$R$ Square & 0.545
\end{tabular}




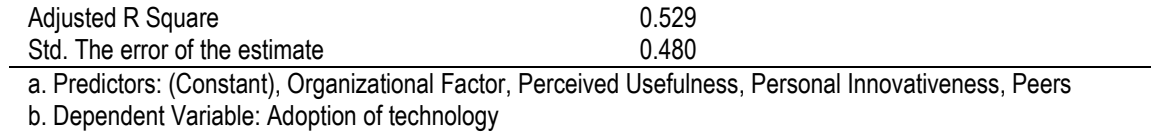

$\mathrm{R}^{2}$ is the coefficient of Determination and represents the extent of changes in the dependent variable that can be explained by the independent variables. It determines how well all the regression lines fit the data. It is a number ranging from 0 to $1(1>\mathrm{R} 2>0)$, and it represents the proportion of the total variation in the dependent variables explained by the regression equation.

The model summary table shows the $\mathrm{R}$ regression of four independent variables, which are an organizational factor, perceived usefulness, personal innovativeness, and peers, to 0.738 . The generated inter-correlation $R$ square (R2) is 0.545 , which is when translated, refers to about $54.5 \%$ of the four independent variables that can explain the dependent variable. By referring to the rule of thumb, the remaining $45.5 \%$ cannot be explained by the regression analysis. It could be inferred here that other factors could influence the adoption of technology among teachers in rural areas, such as skills and knowledge.

\subsection{Multiple Regression Analysis}

Table 5: Regression Analysis of Coefficient

\begin{tabular}{|c|c|c|c|c|c|c|}
\hline \multicolumn{7}{|c|}{ Coefficients } \\
\hline \multirow[t]{2}{*}{ Model } & & \multicolumn{2}{|c|}{ Unstandardized Coefficients } & \multirow{2}{*}{$\begin{array}{l}\text { Standardized Coefficients } \\
\text { Beta }\end{array}$} & \multirow[t]{2}{*}{$t$} & \multirow[t]{2}{*}{ Sig. } \\
\hline & & B & Std. Error & & & \\
\hline \multirow[t]{5}{*}{1} & (Constant) & 0.802 & .313 & & 2.566 & .012 \\
\hline & Organizational Factor & -0.183 & .115 & -0.173 & -1.587 & .115 \\
\hline & Perceived Usefulness & 0.430 & .107 & 0.441 & 4.027 & .000 \\
\hline & Personal Innovativeness & 0.186 & .083 & 0.168 & 2.247 & .027 \\
\hline & Peers & 0.406 & .139 & 0.370 & 2.919 & .004 \\
\hline
\end{tabular}

a. Dependent Variable: Adoption of technology

The regression analysis of the coefficient test, as exhibited in Table 5, is used to test the coefficient between the independent and dependent variables. The results from the table show that the Beta of organizational factor is $(-0.183)$, followed by perceived usefulness (0.430), personal innovativeness (0.186), and peers (0.406). Based on the results, perceived usefulness has the highest impact on technology adoption among teachers in rural area schools in the Segamat district, with its Beta value equaling 0.430 .

Only three variables are significant predictors to the adoption of technology among the teachers: perceived usefulness $(p=0.00)$, personal innovativeness $(p=0.27)$, and peers $(p=0.004)$. On the other hand, organizational factors are not predictors of the adoption of technology among teachers in rural schools $(p=0.115)$. Based on the regression analysis results, it can be concluded that perceived usefulness is a factor that primarily influences the adoption of technology among teachers, with t-value (4.027) and Beta value (0.430) being the highest among all variables.

\subsection{Discussion}

This study revealed three variables that carry significant predictors towards the adoption of technology among teachers in a rural school in the Segamat district: (1) personal innovativeness, (2) perceived usefulness, and (3) peers. For personal innovativeness, it is also in line with the past study by Aziz et al. (2021), Samuel (2014), Thongmak (2017), and Thanakrit et al. (2019), where they mentioned this system could influence and give a good perception and good experience for the user. Furthermore, personal innovativeness explained the new introduction of a system that is used in teaching and learning, and this study was found similar to the study that did by Bambang, 2019. Meanwhile, for peers, it stated that using ICT for teaching can give support and encouragement for teachers. This study is in line with Mai \& Hong 2014; Duyen, 2014. Although Sherry and Gibson (2002) recommended organizational factors should be accounted for in determining technology adoption, it is not supported in this study where organizational factors had no significant predictor towards the adoption of technology among teachers with substantial values of beta -0.183 and sig value of 0.115 , respectively.

\subsection{Conclusion \& Recommendations}

Overall, this study examined the determinants that contributed to the adoption of technology among teachers and implemented it in rural schools located in the district of Segamat, Johor. This study found three factors with significant relationships to technology adoption among teachers, as stated in table 3. The teachers felt that it was easier for them to use technology in technology usage if the platforms or applications were friendly to operate. It was because their level of mastery depended on the extent to which the online platform was usable. In addition, the teachers' innovative skills also helped them explore technology and were supported by the knowledge they had. The more knowledgeable they are, the higher their innovativeness in the adoption of technology. Next, the adoption of technology also included supports from peers. The majority of the teachers believe that they get influenced by their colleagues to use technology. Among the teachers, they communicated and shared ideas and knowledge on adapting technology in their teaching and learning sessions. It would be easier for the teachers to understand the interface and features in an online teaching platform as guidance by peers. This study recommends that school administrations provide support for their teachers to ensure the effectiveness of technology use in class, especially in rural schools area. Lastly, the relevant ministries can also increase teacher training to help them master the maximum use of 
technology in teaching and learning processes. Suggestion for further researchers is to add or replace other independent variables to measure the technology adoption among teachers in other's rural areas.

\section{Acknowledgment}

Special thanks to UiTM Cawangan Johor for funding our research with BESTARI Research Grant. We also would like to thank the survey respondents for taking their time to answer the questionnaire and this paper's reviewers for their valuable comments.

\section{Paper Contribution to Related Field of Study}

This research contributes to filling the gap of the existing literature that is related to the study of School Teacher's Technology Adoption.

\section{References}

Abd Aziz, N.A. et al. Determinants of UiTM Johor Students' Behavioral Intention to Use E-Learning System. International Journal of Engineering \& Technology, [S.I.], v. 7, n. 3.35, p. 196-199, Sep. 2018. ISSN 2227-524X. Available at: Date accessed: April 18. 2021. doi:http://dx.doi.org/10.14419/ijet.v7i3.35.29296

Agyei, D. D., \& Voogt, J. M. (2011). Exploring The Potential Of The Will, Skill, Tool Model In Ghana: Predicting Prospective And Practicing Teachers' Use Of Technology. Computers \& Education, 56(1), 91-100. http://dx.doi.org/10.1016/j.compedu.2010.08.017

Andoh, C. B. (2012). Factors Influencing Teachers' Adoption And Integration Of Information And Communication Technology Into Teaching: A Review Of The Literature. International Journal of Education and Development using Information and Communication Technology (IJEDICT), 2012, Vol. 8, Issue 1, pp. 136-155.

Aziz, N. A. binti A., Musa, M. H. bin, Aziz, N. N. binti A., Malik, S. binti A., \& Khalid, R. binti M. (2020). A Study on Barriers Contributing to an Effective Online Learning Among Undergraduates' Students. Open Journal of Science and Technology, 3(1), 17-23. https://doi.org/10.31580/ojst.v3i1.1359

Bambang Leo Handoko. 2019. Application of UTAUT Theory in Higher Education Online Learning. In Proceedings of the 201910 th International Conference on E-business, Management and Economics (ICEME 2019). Association for Computing Machinery, New York, NY, USA, 259-264. DOI: https://doiorg.ezaccess.library.uitm.edu.my/10.1145/3345035.3345047

Brinkerhoff, J. (2006). Effects Of A Long-Duration, Professional Development Academy On Technology Skills, Computer Self-Efficacy, And Technology Integration And Beliefs. Journal of Research on Technology in Education, 39(1), 22-43.

Davis FD, Bagozzi RP, Warshaw PR (1992). Extrinsic And Intrinsic Motivation To Use Computers In The Workplace. J. Appl. Soc. Psychol. 22(14): 1109-1130.

Davis, F.D., 1989. Perceived Usefulness, Perceived Ease of Use, and User Acceptance of Information Technology. MIS Quarterly. 13, 3, 319-340. DOI= http://dx.doi.org/10.2307/249008.

Dinh, H. (2009). Factors influencing EFL Novice Teachers' Adoption of Technologies. CamTESOL Conference on English Language Teaching: Selected Papers, 5, 99-112. Available at http://www.camtesol.org/Download/Earlier_Publications/Selected_Papers_Vol.5_2009.pdf

Donald E. Wynn and Thomas W. Ferratt. 2019. A Strategic View of IT and Innovativeness. In Proceedings of 2019 on Computers and People Research Conference (SIGMISCPR '19). Association for Computing Machinery, New York, NY, USA, pg 67-76. DOI: https://doi-org.ezaccess.library.uitm.edu.my/10.1145/3322385.3322401

Duyen, L.T.H., (2014 ). Learning to Teach ESP: Case Studies of Two Vietnamese General English Teachers. Language Education in Asia, 2014, 5(2), 228-237. http://dx.doi.org/10.5746/LEiA/14/V5/l2/A05/Duyen

Goktalay, S.B. \& Ocak, M.A (2006). Faculty Adoption Of Online Technology In Higher Education. The Turkish Online Journal of Educational Technology - TOJET October 2006 ISSN: 1303-6521 volume 5 Issue 4 Article 5

Ferri, F., Grifoni, P., \& Guzzo, T. (2020). Online Learning and Emergency Remote Teaching: Opportunities and Challenges in Emergency Situations. Societies, $10(4), 86$. https://doi.org/10.3390/soc10040086

Holley, D. (2002). 'Which room is the virtual seminar in, please?'. 112https://doi.org/10.1108/00400910210424283

Kotrlik, J.W., \& Redmann, D. H., (2009). A Trend Study: Technology Adoption in the Teaching-Learning Process by Secondary Agriscience Teachers-2002 and 2007. Journal of Agricultural Education. Pg 64-76, Volume 50, Number 2, 2009

Lau, B.T., Sim, C.H (2008). Exploring The Extent Of Ict Adoption Among Secondary School Teachers In Malaysia. International Journal of Computing and ICT Research, Vol. 2, No. 2, December 2008, pg 19-36

Mai, L.X., \& Hong, V.K., (2014). Factors Affecting Secondary-School English Teachers' Adoption of Technologies in Southwest Vietnam. Language Education in Asia, 2014, 5(2), 198-215. http://dx.doi.org/10.5746/LEiA/14/V5//2/A03/Le_Vo

Mereku, D. K., Yidana, I., Hordzi, W., Tete-Mensah, I., Tete-Mensah, W., \& Williams, J. B. (2009). Ghana report. ERNWACA University of Education, Winneba, Ghana. Neyland, E. (2011). Integrating online learning in NSW secondary schools: Three schools' perspectives on ICT adoption. Australia Journal of Educational Technology, vol. 27 , no. 1 , pp. $152-173$

Mohamed Noh, N., Ahmad Mustafa, H. M., Hamzah, M., Ismail, M. A., \& Abdullah, N. (2013). Penggunaan Inovasi Teknologi Dalam Pengajaran: Cabaran Guru Dalam EPembelajaran. Proceedings Of The 7th International Malaysian Educational Technology Convention (IMETC 2013), Technology Enhanced Global Classroom Environment, $1-12$. 
Rangaswamy, A. and S. Gupta. 2000. Innovation adoption and diffusion in the digital environment: some research opportunities.

Rogers, E.M. (2003). Diffusion of innovations. New York: Free Press

Schoepp, K. (2005). Barriers to Technology Integration. Online Submission.

Sherry, L., \& Gibson, D. (2002). The path to teacher leadership in educational technology. Contemporary issues in technology and teacher education, vol. 2, no. 2, pp. 178203.

Samuel Fosso Wamba. 2014. Perceived usefulness, ease of use and risk in Social Media Adoption within Workspace: An Empirical Study Integrating Assessment of Unobserved Heterogeneity in PLS Path Modeling. In Proceedings of the Sixteenth International Conference on Electronic Commerce (ICEC '14). Association for Computing Machinery, New York, NY, USA, 20-26. DOI:https://doi-org.ezaccess.library.uitm.edu.my/10.1145/2617848.2617852

Sangeeta, \& Tandon, U. (2020). Factors influencing adoption of online teaching by school teachers: A study during COVID-19 pandemic. Journal of Public Affairs, September 1-11. https://doi.org/10.1002/pa.2503

Tearle, P. (2004). A theoretical and instrumental framework for implementing change in ICT in education. Cambridge Journal of Education, 34(3), 331-351. http://dx.doi.org/10.1080/0305764042000289956

Thomas, R., Adams, M., Meghani, N., \& Smith, M. (2002). Internet integration in high schools: Patterns, opportunities, and barriers. St. Paul, MN: National Research Center for Career and Technical Education. (ERIC Document Accession No. ED 476034). Retrieved May 24, 2007, from http://www.nccte.org/publications/infosynthesis/r\&dreport/ Internet_Integration.pdf

Thongmak, M.: Flipping MIS classroom by Peers: gateway to student's engagement intention. In: Proceedings of the 26th International Conference on World Wide Web Companion, pp. 387-396 (2017)

Thanakrit Maleesut, Poramin Piyawattanaviroj, and Pratchayapong Yasri. 2019. Gen X STEM Teachers' Perceived Usefulness and Challenges of a blended learning System. In Proceedings of the 2019 3rd International Conference on Education and Multimedia Technology (ICEMT 2019), Association for Computing Machinery, New York, NY, USA, 104-106. DOl:https://doi.org/10.1145/3345120.3345166

Voogt, J., and G. Knezek. 2008. "IT in Primary and Secondary Education: Emerging Issues." In International Handbook of Information Technology in Primary and Secondary Education, edited by J. Voogt, and G. Knezek, xxix-xxxix. New York: Springer Science Business Media.

Williams, M. D. (2003). Technology integration in education. In Tan, S.C. \& Wong, F.L. (Eds.), Teaching and Learning with Technology, pp. 17-31: An Asia-pacific perspective. Singapore: Prentice-Hall.

Ya'acob, A., Nor, N., And Azman, H. 2005. Implementation of the Malaysian Smart School: An Investigation of Teaching-Learning Practices and Teacher-Student Readiness. Internet Journal of e-Language Learning \& Teaching, 2(2), pp. 16-25.

Zaltman, G., Duncan, R. and Holbek, J. (1973), Innovations and Organisations, John Wiley \& Sons, New York, NY. 